\title{
STATUS KUALITAS PERAIRAN UMUM DAN AIR TANAH DI WILAYAH JAKARTA
}

\author{
Oleh : \\ Suhendar I. Sachoemar dan Heru Dwi Wahjono
}

Peneliti BPPT

\begin{abstract}
The environment and water quality status of the open waters of the rivers and lake including ground water surround DKI Jakarta was evaluated on the base of the data collected by local government of the environmental agency of DKI Jakarta (BPLHD) period of 2004. The result shows that water quality of those open waters has degraded due to the impact of the domestic and industrial waste that flowing through the rivers. The $D O$, total suspended solid (TSS), ammonia, organic matter, BOD and COD of the open waters in general have more than intemperate of the environmental standard of the water quality for drinking, fisheries, animal husbandry and industrial need. While the ground water has degraded due to the increasing of the Fe, Mn and detergent. To eliminate and minimize the degradation of the water quality of the open waters and ground water surround Jakarta, strict regulation should be established following the regular monitoring of the whole area of the open and ground waters.
\end{abstract}

Katakunci : Kualitas Perairan Umum, Sungai, Situ, Air Tanah, DKI Jakarta.

\section{PENDAHULUAN}

\subsection{Latar Belakang}

Perairan umum yang meliputi sungai, situ dan sistem akuifer dalam tanah merupakan salah satu komponen lingkungan yang saat ini perlu mendapatkan perhatian khusus, terutama yang berhubungan dengan masalah sumber daya air dan kualitas air yang ada di dalamnya. Cepatnya laju peningkatan pembangunan di DKI Jakarta secara langsung maupun tidak langsung akan berdampak terhadap terjadinya kerusakan lingkungan termasuk di dalamnya pencemaran sungai baik yang disebabkan oleh limbah domestik maupun limbah industri.

Kondisi geografis wilayah DKI Jakarta dilewati oleh 13 sistem aliran sungai yang sebagian besar berhulu di daerah Jawa Barat dan bermuara di Teluk Jakarta. Karena sungaisungai yang melintasi wilayah Jakarta berada di bagian hilir, maka sungai-sungai tersebut merupakan tempat limpahan buangan limbah yang berasal dari Jawa Barat dan bermuara di pantai Utara Jakarta sebagai tempat buangan terakhir air limbah. Sementara sungai-sungai tersebut difungsikan sebagai sumber air baku air minum dan berbagai kegiatan ekonomi masyarakat DKI Jakarta.

Untuk mengurangi dampak pencemaran dan menanggulangi pencemaran yang sudah terjadi, pemerintah daerah DKI Jakarta telah melakukan kegiatan pemantauan kualitas air secara rutin pada badan-badan sungai dan beberapa zona perairan di pantai Utara DKI Jakarta. Selain itu Gubernur DKI Jakarta juga telah mengeluarkan Surat Keputusan No. 582
Tahun 1995 tentang Penetapan Peruntukan Baku Mutu Air Sungai/Badan Air serta Baku Mutu Limbah Cair di wilayah DKI Jakarta.

Melalui kegiatan pemantauan kualitas air perairan umum secara rutrin yang telah dilakukan oleh instansi BPLHD Propinsi DKI Jakarta, diharapkan dapat diperoleh informasi yang dapat dijadikan sebagai dasar untuk menentukan berbagai kebijakan dalam usaha pengendalian pencemaran dan pengelolaan perairan umum secara efektif dan efisien untuk mewujudkan sistem tata kelola lingkungan perairan secara berkelanjutan di wilayah DKI Jakarta.

\subsection{Tujuan Penelitian}

Penelitian ini bertujuan untuk menganalisa, mengevaluasi dan memberikan informasi tentang status kualitas air perairan umum dan air tanah di wilayah DKI Jakarta berdasarkan data hasil pemantauan BPLHD DKI Jakarta.

\section{METODA PENELITIAN}

\subsection{Pengumpulan Data}

Penelitian ini mempergunakan data kualitas perairan umum dan air tanah hasil pemantauan BPLHD DKI Jakarta tahun 2004 yang dikumpulkan dari 66 titik pemantauan dari 13 badan sungai yang mengalir di wilayah DKI Jakarta (Gambar 1). Wilayah pemantauan meliputi wilayah perbatasan DKI Jakarta - Jawa Barat, bagian hilir dan muara sungai di wilayah DKI Jakarta dengan peruntukan sebagai (1) : 1). air baku air minum (Golongan B), 2). perikanan dan peternakan (Golongan C), 3). pertanian dan 
usaha perkotaan (Golongan D). Kegiatan pemantuan dilaksanakan sebanyak 3 kali dalam satu tahun.

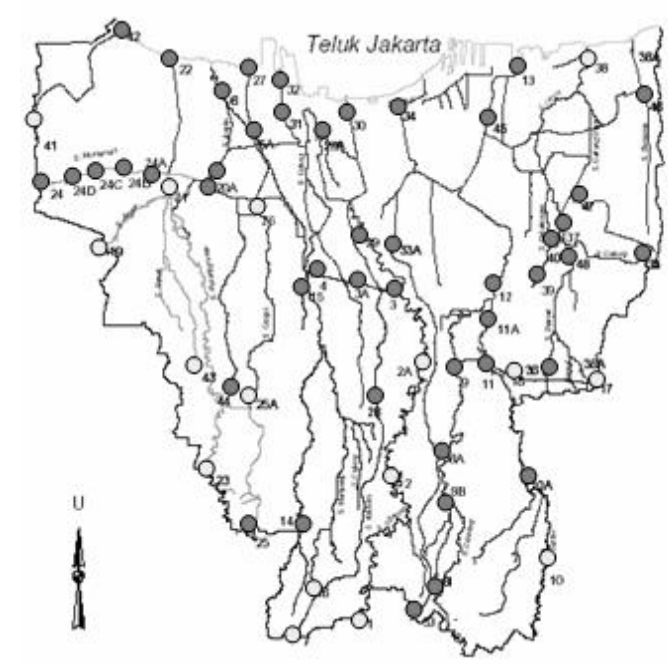

Gambar 1: Lokasi Pemantauan Kualitas Air

Paramater yang diamati adalah paramater fisika, kimia dan biologi yang disesuaikan dengan baku mutu yang telah ditetapkan SK Gubernur DKI No. 582 Tahun 1995.

\subsection{Analisa Data}

Analisa data fisika dan kimia dilakukan dengan membandingkan data hasil pemantauan dengan baku mutu yang telah ditetapkan oleh SK Gubernur DKI Jakarta No. 582 Tahun 1995 tentang Penetapan Peruntukan dan Baku Mutu Air Sungai / Badan Air Serta Baku Mutu Limbah Cair di Wilayah DKI Jakarta. Untuk parameter biologis dilakukan perhitungan indeks diversitas dari plankton dan benthos, yaitu untuk derajat pencemaran secara ekologis dan perhitungan indeks kualitas air (IKA-NSF) sungai secara keseluruhan (Tabel 1).

Tabel 1: Klasifikasi Derajat Pencemaran

\begin{tabular}{|c|l|}
\hline Indeks Diversitas & \multicolumn{1}{|c|}{ Klasifikasi } \\
\hline$>2.0$ & Belum Tercemar \\
\hline $1,6 \sim 2.0$ & Tercemar Ringan \\
\hline $1.0 \sim 1.5$ & Tercemar Sedang \\
\hline$<1.0$ & Tercemar Berat \\
\hline
\end{tabular}

\section{HASIL DAN PEMBAHASAN}

\subsection{Kondisi Geografi DKI Jakarta}

DKI Jakarta sebagai Ibukota Republik Indonesia, dengan penduduk hampir sepuluh juta jiwa, merupakan salah satu kota terpenting di Asia. DKI Jakarta terdiri dari 5 Kotamadya dan 1 Kota Administratif, yang berkedudukan sebagai daerah tingkat dua, di bawah pengawasan kantor Gubernur. Kelima kotamadya tersebut adalah Jakarta Utara, Jakarta Timur, Jakarta Barat, Jakarta Selatan, Jakarta Pusat dan Kabupaten Kepulauan Seribu.

Wilayah Kotamadya Jakarta Barat memiliki luas wilayah : 12.615,14 $\mathrm{Ha}$ dan terletak antara 106 - 48 BT, 60 - 12 LU dan dibatasi oleh wilayah sebagai berikut: Sebelah Selatan : Kotamadya Jakarta Selatan dan Kabupaten / Kodya Tangerang, Sebelah Barat : Kabupaten dan Kotamadya Tangerang, Sebelah Timur : Kotamadya Jakarta Utara dan Kotamadya Jakarta Pusat, sedangkan Sebelah Utara : Kabupaten / Kodya Tangerang dan Kodya Jakarta Utara. Wilayah ini secara administratif terbagi menjadi 8 Kecamatan dan 56 Kelurahan dengan luas wilayah keseluruhan mencapai $127,11 \mathrm{Km}^{2}$. Jakarta Pusat dengan luas : 48,17 $\mathrm{Km}^{2}$, dengan kondisi topografi relatif datar dan secara administratif dibagi : 8 Kecamatan, 44 Kelurahan, 388 RW dan 4784 RT.

Secara administratif, wilayah Jakarta Selatan terbagi menjadi 10 Kecamatan dan 65 Kelurahan dengan luas keseluruhan mencapai, $145,73 \mathrm{Km}^{2}$. Bagian dari wilayah Jakarta Selatan ini pada masa awal kemerdekaan direncanakan sebagai Kota Satelit (Kebayoran Baru), konsep dengan alusi oriental yang ditandai dengan empat jalan utama yang menyebar dari satu pusat ke empat penjuru dan mengintegrasikan rumah-rumah besar dengan rumah-rumah kecil di dalam setiap blok yang besar di luar, di tepi jalan besar, yang lebih kecil di dalam, mengelilingi taman lingkungan itu kini mulai penuh sesak. Selain itu, bagian wilayah ini juga menjadi penyangga air tanah ibukota yang nasibnya kini mengenaskan karena banyaknya bangunan dan mulai menyurutnya ruang-ruang terbuka hijau. Selain itu, kawasan selatan ini juga mulai tumbuh sebagai pusat perbelanjaan, di samping perumahan yang banyak diminati warga kota.

Wilayah Jakarta Timur terdiri $95 \%$ daratan dan selebihnya rawa atau persawahan dengan ketinggian rata-rata $50 \mathrm{~m}$ dari permukaan air laut serta dilewati oleh beberapa sungai kanal antara lain : Cakung Drain, Kali Ciliwung, Kali Malang, Kali Sunter, Kali Cipinang. Letak geografis berada diantara $106^{\circ} 49^{\prime} 35^{\prime \prime}$ Bujur Timur dan $06^{\circ}$ 10' 37" Lintang Selatan. Beriklim Panas dengan suhu rata-rata sepanjang tahun sekitar 27 derajad celcius. Curah hujan rata-rata $2.000 \mathrm{~mm}$ per tahun sampai dengan maksimum bulan Januari.

Wilayah kotamadya Jakarta Utara memiliki luas $7.133,51 \mathrm{Km}^{2}$, terdiri dari luas lautan 6.979,4 
$\mathrm{Km}^{2}$ dan luas daratan $154,11 \mathrm{Km}^{2}$. Daratan Jakarta Utara membentang dari Barat ke Timur sepanjang kurang lebih $35 \mathrm{~km}$, menjorok ke darat antara $4 \mathrm{~s} / \mathrm{d} 10 \mathrm{~km}$, dengan kurang lebih 110 pulau yang ada di Kep. Seribu. Ketinggian dari permukaan laut antara 0 s/d 20 meter, dari tempat tertentu ada yang dibawah permukaan laut yang sebagian besar terdiri dari rawarawa/empang air payau. Wilayah Kodya Jakarta Utara merupakan pantai beriklim panas, dengan suhu rata-rata $27^{\circ} \mathrm{C}$, curah hujan setiap tahun rata-rata $142,54 \mathrm{~mm}$ dengan maksimal curah hujan pada bulan September.

\subsection{Status Kualitas Perairan Umum}

Keberadaan sungai dan situ atau danau yang merupakan perairan umum di wilayah DKI Jakarta secara ekonomi belum termanfaatkan dan secara ekologi kualitasnya telah banyak mengalami penurunan baik disebabkan oleh limbah organik maupun limbah industri $(2,3,4,5)$. Padahal keberadaan perairan umum tersebut apabila ditata dan dikelola dengan baik untuk kegiatan ekonomi seperti perikanan dan pariwisata dapat menjadi sumber pendapatan daerah dan masyarakat DKI Jakarta.

Perairan umum disamping memiliki fungsi ekologis sebagai penampung limpasan air pada waktu hujan juga berfungsi sebagai oase penyejuk dan penambah keindahan kota apabila dikelola dan dimanfaatkan dengan baik. Agar perairan umum di wilayah DKI Jakarta dapat dimanfaatkan dan dikelola dengan baik, maka perlu dilakukan penataan dan pendataan secara tepat kemudian dilakukan perencanaan pengelolaan dan pemanfaatannya secara tepat dengan memperhatikan aspek fungsi ekologis, ekonomis dan estetika secara tepat. Untuk itu maka perlu dibuatkan perencanaan penataan dan strategi pengembangannya secara sistimatis, fungsional dan berkelanjutan ${ }^{(6,7)}$.

\subsubsection{Kualitas Perairan Sungai}

Berdasarkan laporan BPLHD DKI Jakarta tahun 2004 diketahui bahwa kualitas perairan sungai baik secara fisik, kimia dan biologi telah banyak mengalami penurunan. Sebagian besar atau bahkan hampir keseluruhan perairan sungai yang mengalir melintasi wilayah DKI Jakarta termasuk kategori sedang hingga buruk kualitasnya $(2,3,4,5)$. Beberapa parameter penting seperti oksigen terlarut (DO), padatan tersuspensi (TSS), ammonia, minyak, bahan organik, BOD dan COD telah melebihi ambang batas baku mutu baik untuk Golongan B (air minum), Golongan C (perikanan dan peternakan) dan Golongan D (perkotaan atau industri).
Secara umum kondisi kualitas perairan sungai di wilayah DKI Jakarta seperti yang dilaporkan oleh BPLHD DKI Jakarta tahun 2004 adalah sebagai berikut :

a. Kualitas fisik. Sungai-sungai yang termasuk golongan B (peruntukan air baku air minum), masih memenuhi baku mutu untuk parameter daya hantar listrik, zat padat tersuspensi, dan zat padat terlarut, sedangkan untuk parameter DO dan kekeruhan di beberapa lokasi telah melebihi baku mutu. Sedangkan untuk sungai dengan golongan C (peruntukan perikanan dan peternakan) masih memenuhi baku mutu hanya pada parameter TDS sedangkan parameter lainnya telah melebihi baku mutu. Untuk sungai dengan golongan D (peruntukan usaha perkotaan) telah melebihi baku mutu pada semua parameter fisik.

b. Kualitas kimia. Kandungan nitrat masih memenuhi baku mutu, sedangkan parameter yang telah melebihi adalah Phosphat, Organik, BOD, dan COD, kesemua parameter ini merupakan bahan organik yang kemungkinan besar berasal dari limbah domestic/rumah tangga. Sedangkan untuk parameter logam masih memenuhi baku mutu. Hal ini terjadi hampir di semua lokasi baik itu pada sungai dengan golongan $B$, golongan $\mathrm{C}$, maupun golongan $\mathrm{D}$.

c. Kualitas mikrobiologi. Untuk parameter Coliform dan Fecal coli telah melebihi baku mutu di semua lokasi pemantauan.

Sedangkan berdasarkan Indeks Kualitas Air (IKA), diketahui bahwa Kualitas Air sungai di DKI Jakarta yang dipantau pada bulan April, Juli dan Nopember, hanya $2 \%$ atau 1 titik saja dari 66 titik pengamatan yang kualitas airnya dikatagorikan baik. Sedangkan sisanya termasuk kedalam katagori sedang hingga buruk. Dari hasil perhitungan tersebut, sungai Ciliwung, sungai Cakung, sungai Grogol, sungai Angke, dan sungai Sunter termasuk kedalam kategori sedang dan buruk. Sementara untuk sungai Mookervart dan sungai Cipinang termasuk dalam kategori buruk (Tabel 2).

Berdasarkan nilai IKA bulan April, Juli dan Nopember maka persentase lokasi pemantauan yang termasuk dalam kategori buruk sebesar $76 \%$ pada bulan april dan menurun menjadi $66 \%$ pada bulan Juli dan $64 \%$ pada bulan Nopember, dan untuk kategori sedang meningkat dari $24 \%$ pada bulan april menjadi $32 \%$ pada bulan Juli, dan $35 \%$ pada bulan Nopember. Pada bulan Juli terdapat kategori baik, tetapi pada bulan Nopember terdapat kategori sangat buruk (BPLHD, 2004). Sebaran kualitas air pada bulan April, Juli dan 
Nopember 2004 berdasarkan Indeks Kualitas Air (IKA) di perairan sungai yang melintasi wilayah
DKI Jakarta selengkapnya terlihat masingmasing pada Gambar 2 dan 3.

Tabel 2 : Jumlah Titik Pemantauan berdasarkan Kategori IKA Sungai di DKI Jakarta Tahun 2004 (1)

\begin{tabular}{|l|c|c|c|c|c|c|}
\hline \multirow{2}{*}{ Kategori } & \multicolumn{2}{|c|}{ April } & \multicolumn{2}{c|}{ Juli } & \multicolumn{2}{c|}{ Nopember } \\
\cline { 2 - 7 } & $\Sigma$ Titik & Persentase & $\sum$ Titik & Persentase & $\Sigma$ Titik & Persentase \\
\hline Sangat Baik & 0 & $0 \%$ & 0 & $0 \%$ & 0 & $0 \%$ \\
\hline Baik & 0 & $0 \%$ & 1 & $2 \%$ & 0 & $0 \%$ \\
\hline Sedang & 16 & $24 \%$ & 21 & $32 \%$ & 23 & $35 \%$ \\
\hline Buruk & 50 & $76 \%$ & 43 & $66 \%$ & 42 & $64 \%$ \\
\hline Sangat Buruk & 0 & $0 \%$ & 0 & $0 \%$ & 1 & $2 \%$ \\
\hline Jumlah Titik & 66 & & 65 & & 66 & \\
\hline
\end{tabular}

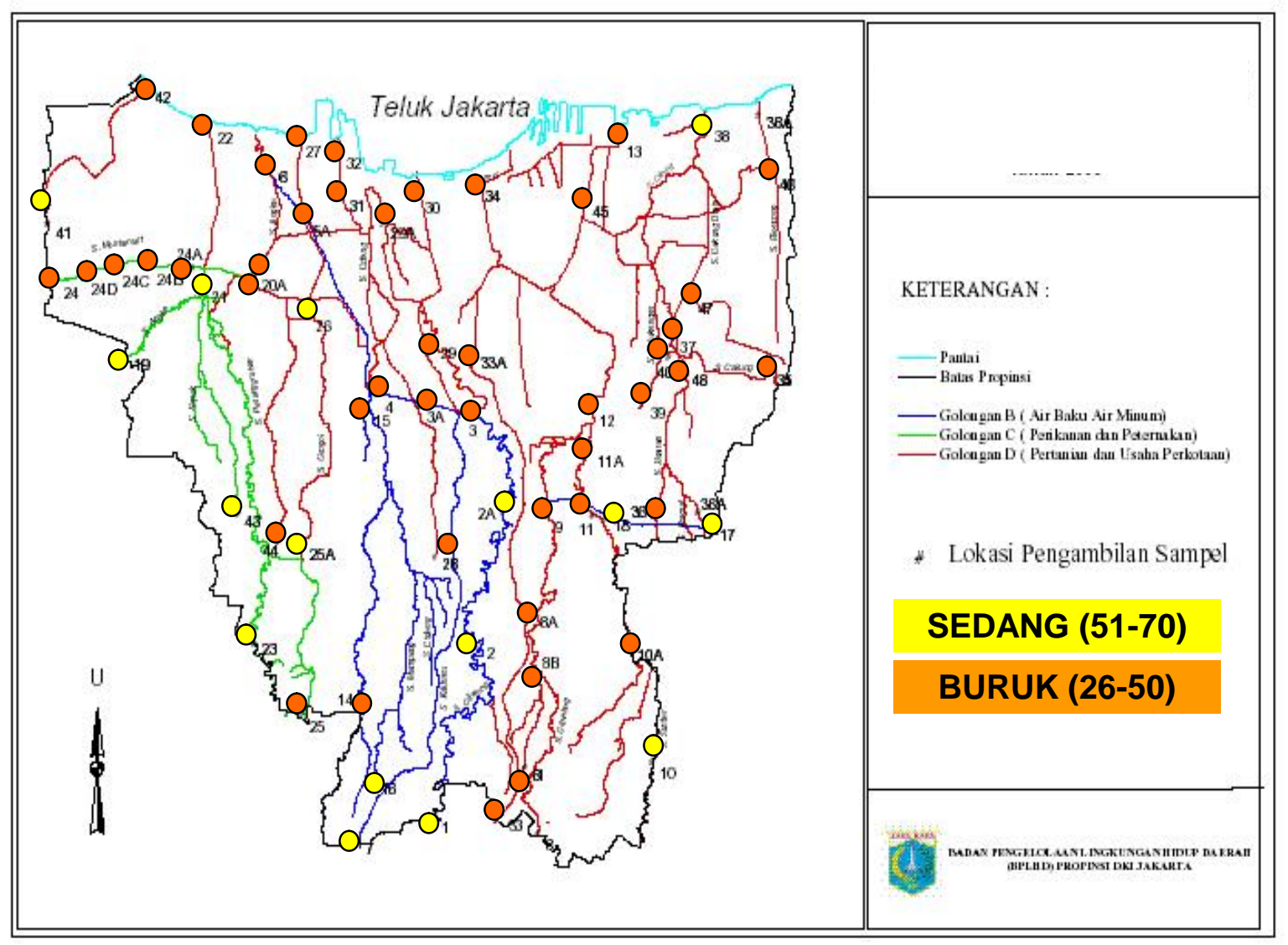

Gambar 2 : Indeks Kualitas Air (IKA) Sungai di DKI Jakarta bulan April 2004 (1) 


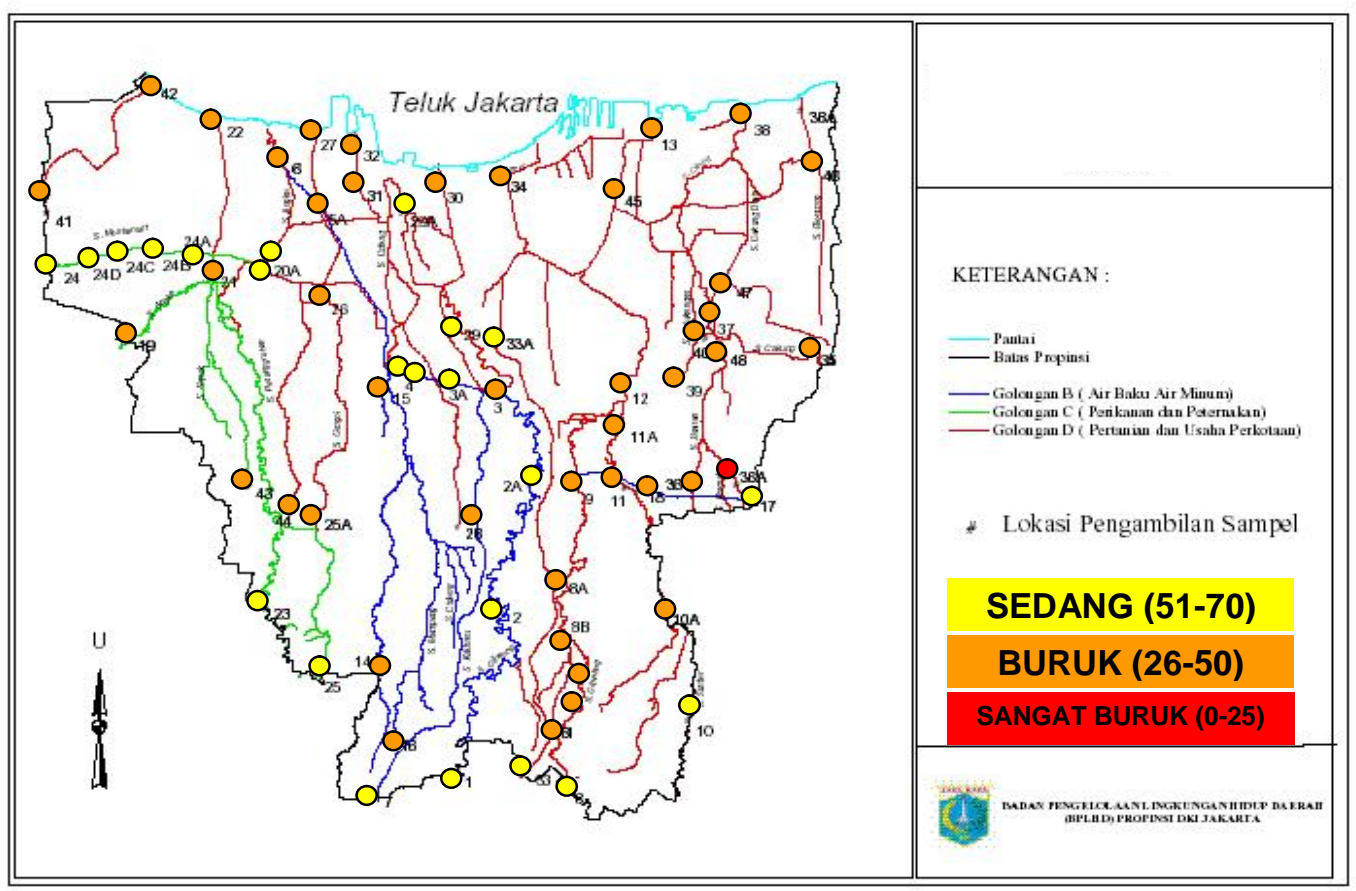

Gambar 3 : Indeks Kualitas Air (IKA) Sungai di DKI Jakarta bulan Juli 2004 (1)

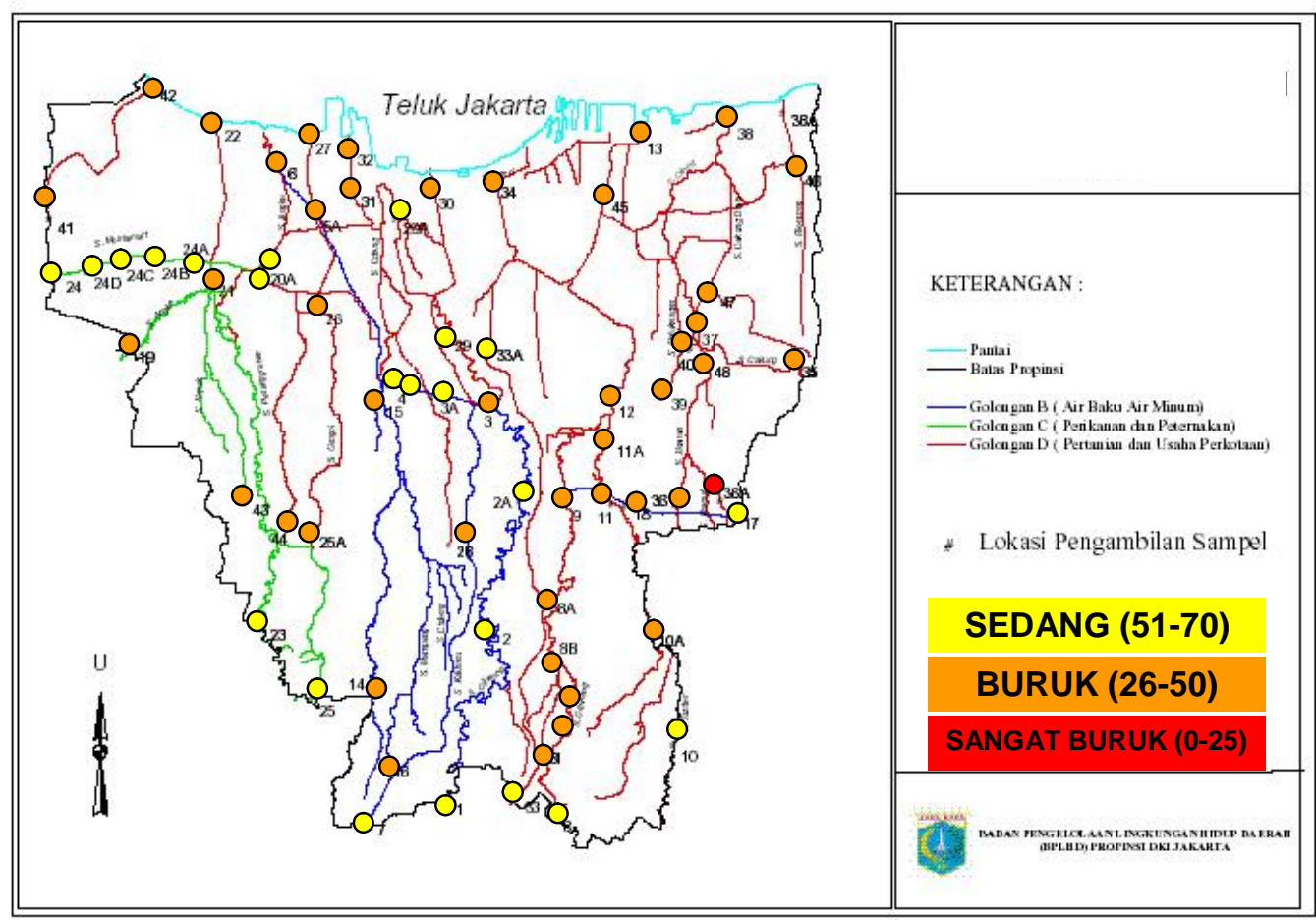

Gambar 4 : Indeks Kualitas Air (IKA) Sungai di DKI Jakarta Bulan Nopember $2004{ }^{(1)}$

Berdasarkan data tersebut terlihat bahwa pada bulan April dan Juli 2004, kualitas air sungai diwilayah DKI Jakarta relatif lebih buruk dibandingkan dengan bulan Nopember. Debit sungai yang rendah disebabkan karena musim kemarau nampaknya telah mempertajam penurunan kualitas air di wilayah DKI Jakarta. Sedangkan pada bulan Nopember yang termasuk ke dalam musim hujan, kualitas airnya cenderung menunjukkan perbaikan walau tidak signifikan. Namun demikian, terdapat satu kejanggalan di satu titik pemantauan di wilayah Jakarta Timur pada bulan Juli dan Nopember 2004, dimana terdapat lokasi perairan yang kualitasnya tergolong sangat buruk. Diduga lokasi tersebut merupakan lokasi kawasan industri di wilayah DKI Jakarta. 
Mengingat kondisi kualitas perairan yang semakin menurun dari waktu ke waktu dan tahun ke tahun, nampaknya upaya pemantauan dan pengendalian kualitas perairan di wilayah DKI Jakarta perlu terus ditingkatkan dan diintensifkan secara lintas sektoral dengan melibatkan berbagai organisasi pemerintahan, industri dan sosial kemasyarakatan untuk menekan dan mengurangi laju peningkatan baik limbah organik maupun industri di seluruh perairan sungai yang melintas wilayah DKI Jakarta.

\subsubsection{Kualitas Air Situ}

Seperti halnya perairan sungai, perairan situ atau danau yang tersebar di wilayah DKI Jakarta (Gambar 5) hampir tidak ada yang mengalami penurunan kualitasnya baik disebabkan oleh limbah domestik maupun limbah industri. Untuk beberapa situ yang terdapat di wilayah utara Jakarta bahkan kondisinya tergolong buruk. Berdasarkan laporan BPLHD DKI Jakarta tahun 2004, kualitas perairan situ di wilayah DKI Jakarta di beberapa lokasi pengamatan (Gambar 6) adalah sebagai berikut :

a. Kualitas Fisik. Kondisi situ di wilayah Jakarta Timur untuk parameter fisiknya telah melampui baku mutu terutama pada situ Pedongkelan, sedangkan pada situ Rio - Rio hanya parameter Daya Hantar Listrik (Conductivity) yang telah melampui baku mutu. Untuk wilayah Jakarta Barat situ Tomang dan Rawa Kepa hanya DHL saja yang telah melampui baku mutu. Untuk wilayah Jakarta Utara, situ Sunter I dan Sunter II secara umum parameter fisik masih berada di bawah baku mutu hanya parameter DHL yang telah melampui BM. Sedangkan pada situ PIK Utara, PIK Selatan dan situ Pademangan terdapat keseragaman yaitu parameter DHL, TDS dan TSS telah melampui baku mutu. Sedangkan untuk situ Teluk gong semua parameter fisiknya telah melebihi baku mutu. Pada wilayah Jakarta Pusat dan Jakarta Selatan kondisi kualitas fisik secara umum masih berada di bawah baku mutu, hanya pada situ Kalibata (Jakarta Selatan) DHL nya telah melampui baku mutu.

b. Kualitas Kimia. Kualitas kimia situ - situ di seluruh wilayah DKI Jakarta menunjukkan bahwa secara umum untuk semua parameter baik BOD, COD, DO, Organik, Deterjen (MBAS), Phospat telah melampui baku mutu yang telah ditetapkan.

c. Kualitas Mikrobiologi. Kualitas mikrobiologi situ di wilayah DKI Jakarta untuk parameter Coliform maupun Fecal Coli secara keseluruhan telah melampaui baku mutu yang telah ditetapkan, hanya pada situ - situ tertentu saja yang konsentrasi Coliform dan Fecal Coli berada di bawah baku seperti pada situ Sunter I ( Jakarta Utara ), situ Kalibata dan Babakan ( Jakarta Selatan ).

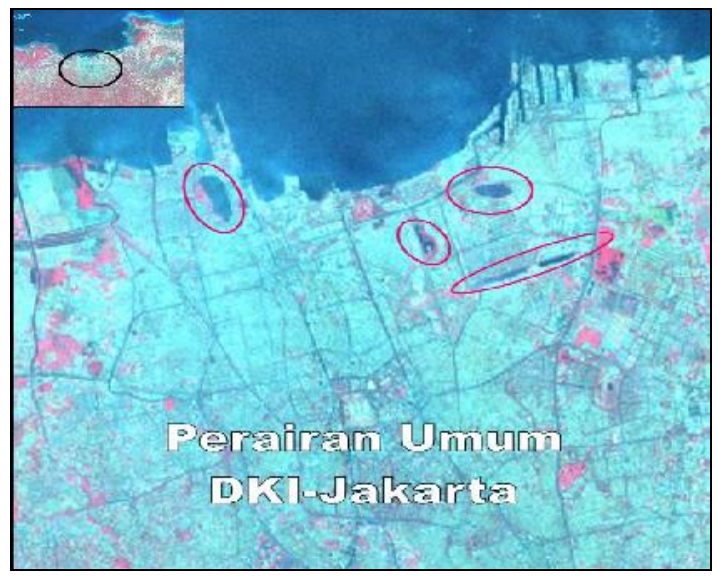

Gambar 5 : Sebaran perairan umum (sungai dan situ) di wilayah DKI Jakarta.

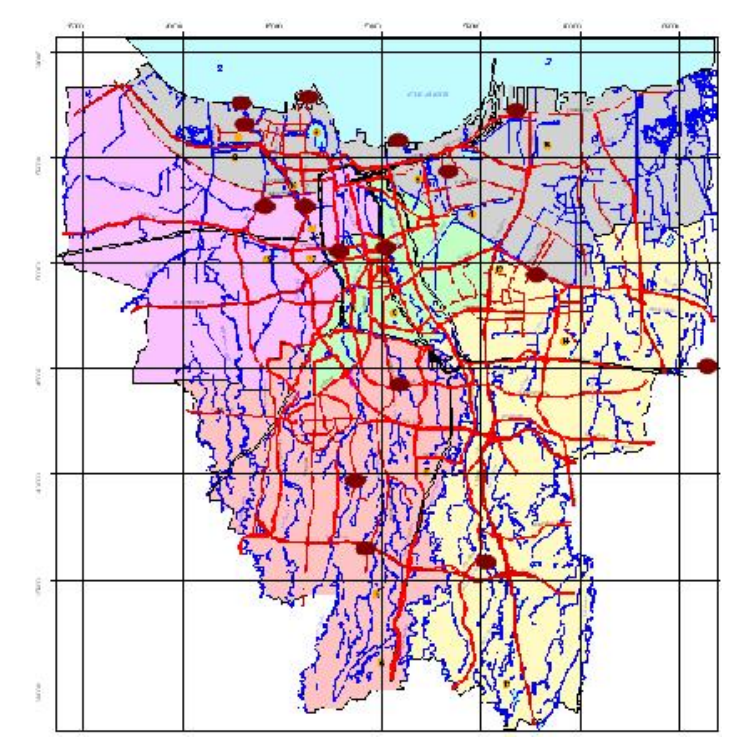

Gambar 6 : Lokasi Pemantauan Kualitas Air Situ/Waduk Tahun 2004 (1)

Berdasarkan Indeks Kualitas Air (IKA) dapat diketahui bahwa Kualitas Air situ/waduk di DKI Jakarta pada tahun 2001 dan 2004 tergolong kedalam katagori sedang dan buruk (Gambar 7). Pada tahun 2004, jumlah situ yang termasuk ke dalam katagori buruk lebih sedikit dibandingkan dengan tahun 2001, yaitu masing-masing 5 untuk tahun 2004 dan 7 untuk tahun 2001. Situ-situ yang berada di wilayah Jakarta Utara dan Barat, kebanyakan tergolong kedalam katagori buruk kualitasnya. Nampaknya semakin ke utara dan barat, kualitas air situ semakin buruk, karena lokasinya di hilir, maka sifatnya hampir menyerupai perairan muara tempat terkumpul dan terakumulasinya setiap jenis bahan pencemar perairan. 


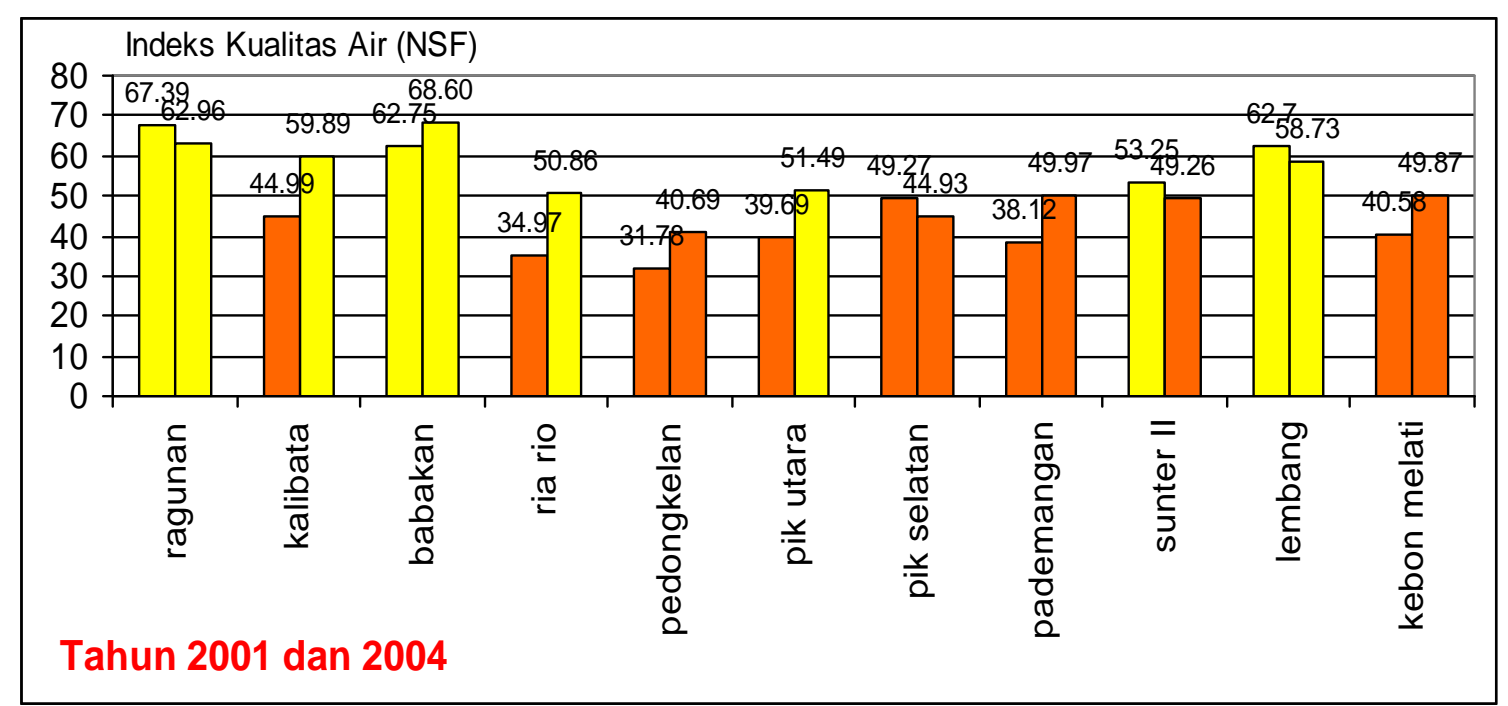

Keterangan :

- Warna kuning = kategori sedang

- Warna oranye = kategori buruk

Gambar 7 : Indeks Kualitas Air (IKA) Situ/Waduk di DKI Jakarta Tahun 2001 dan 2004 (1)

\subsection{Status Kualitas Air Tanah/Sumur}

Seperti halnya air situ, kualitas air tanah di wilayah DKI Jakarta juga kebanyakan tergolong ke dalam kualitas rendah terutama di kawasan Jakarta Utara dan Barat. Berdasarkan laporan BPLHD (2004), penyebab utama terjadinya penurunan kualitas air tanah adalah besi (Fe), Mangan (Mn) dan detergen ${ }^{(8,9)}$. Laporan selengkapnya adalah sebagai berikut :

a. Kualitas Fisik Air Tanah. Hasil pemantauan air tanah di Propinsi DKI Jakarta, pada bulan Juni dan Oktober untuk parameter fisik secara umum masih cukup bagus.

b. Kualitas Kimia Air Tanah. Persentase jumlah sumur yang telah melebihi baku mutu pada periode Juni dan Oktober untuk parameter besi (Fe) adalah sebesar 15\%. Pada wilayah Jakarta Utara dan Barat, persentase jumlah sumur yang telah melebihi baku mutu cenderung mengalami peningkatan (persentase peningkatan sebesar 11\%) dari bulan Juni ke bulan Oktober, sedangkan di Jakarta Pusat dan Jakarta Timur terlihat menurun. Sedangkan untuk parameter Mangan (Mn), persentase jumlah sumur yang melebihi baku mutu Mn di seluruh wilayah DKI Jakarta secara umum sebesar $27 \%$ pada bulan Juni dan meningkat pada bulan Oktober sebesar 33\%. Peningkatan terutama terdapat di wilayah Jakarta Selatan, Jakarta Barat, Jakarta Utara. Sedangkan di Jakarta Timur dan Jakarta
Pusat terlihat turun dan tetap. Untuk parameter Deterjen (MBAS), persentase jumlah sumur yang melebihi baku mutu di DKI Jakarta sebesar 29\% pada bulan Juni dan meningkat menjadi $46 \%$ pada bulan Oktober. Peningkatan yang signifikan terutama di Jakarta Selatan, Jakarta Barat, Jakarta Timur, dan Jakarta Utara.

c. Kualitas Mikrobiologi Air Tanah. Untuk parameter Coliform terjadi peningkatan persentase jumlah sumur yang melebihi baku mutu yaitu sebesar $63 \%$ di bulan Juni meningkat menjadi $67 \%$ pada bulan Oktober di DKI Jakarta. Peningkatan terjadi di wilayah Jakarta Pusat, Jakarta Timur, dan Jakarta Utara. Sedangkan di wilayah Jakarta Selatan dan Jakarta Barat cenderung turun dan tetap. Untuk parameter Fecal coli persentase jumlah sumur yang melebihi baku mutu secara umum mengalami penurunan dari $75 \%$ di bulan Juni menjadi $58 \%$ di bulan Oktober.

Dibandingkan dengan logam berat, persentase jumlah sumur atau air tanah yang tercemar coli dan fecal coli lebih banyak di wilayah DKI Jakarta baik pada musim kemarau maupun musim hujan. Persentase jumlah sumur di DKI Jakarta yang telah melebihi baku mutu untuk parameter Mangan, Besi, Deterjen, Coliform, dan Fecal Coli pada bulan Juni dan Oktober tahun 2004 terlihat pada Gambar 8. 


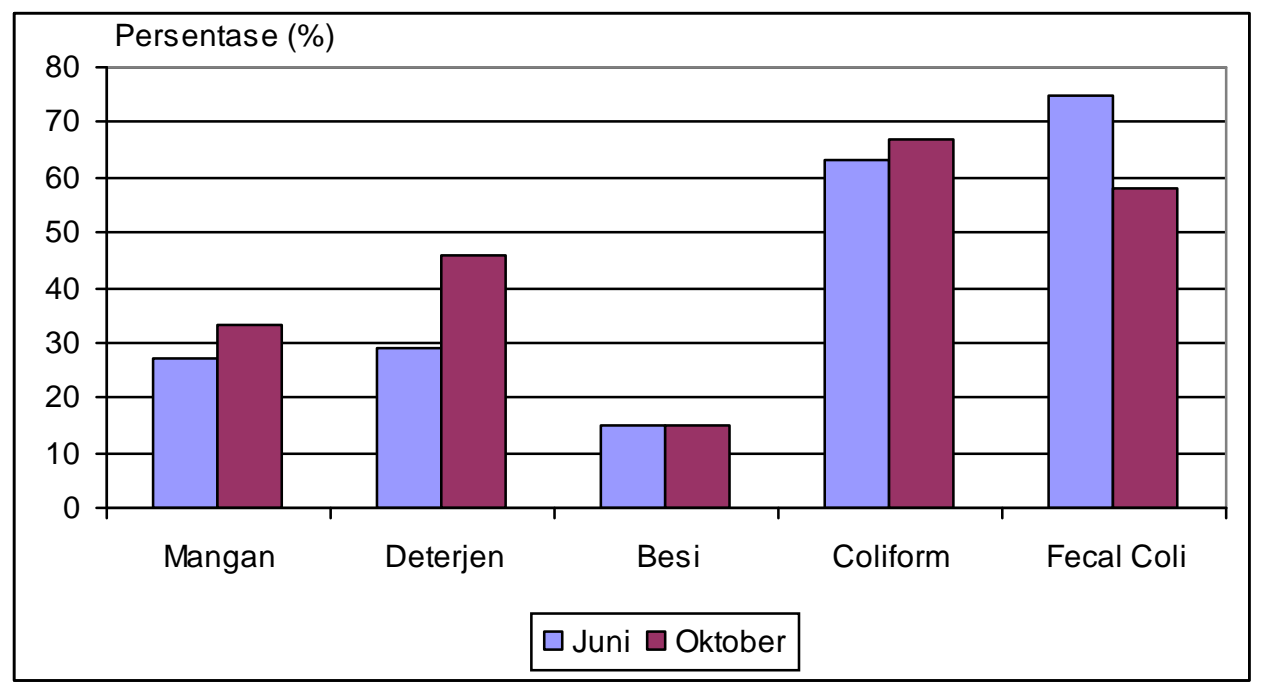

Gambar 8: Persentase Jumlah Sumur di DKI Jakarta yang Melebihi Baku Mutu bulan Juni dan Oktober 2004 (1)

\section{KESIMPULAN}

Kondisi kualitas perairan umum sungai, situ dan air tanah di wilayah DKI Jakarta telah mengalami penurunan akibat berbagai limbah baik limbah domestik maupun limbah industri yang masuk melalui 13 badan sungai mulai dari hulu di perbatasan DKI Jakarta-Jawa Barat dan Banten hingga muara sungai di Teluk Jakarta. Kondisi oksigen terlarut (DO), padatan tersuspensi (TSS), ammonia, bahan organik, BOD dan COD secara umum telah melebihi ambang batas baku mutu air yang ditentukan untuk air minum (Golongan B), perikanan dan peternakan (Golongan C) dan perkotaan atau industri (Golongan D). Sementara air tanah kualitasnya telah menurun disebabkan oleh meningkatnya kandungan besi (Fe), Mangan $(\mathrm{Mn})$ dan detergen. Untuk meminimalkan dampak limbah domestik dan industri terhadap kualitas air perairan umum dan air tanah di wilayah DKI Jakarta, maka penegakkan aturan yang berlaku perlu ditegakkan disertai dengan pemantauan kualitas perairan secara teratur dan rutin.

Untuk menjaga kebersihan perairan umum secara berkelanjutan, penataan bantaran sungai dan pemukiman disekitas situ yang disertai dengan penyediaan fasilitas kebersihan perlu ditingkatkan dan diperbaiki. Perhatian khusus perlu diarahkan ke industri agar secara sadar dapat menyediakan fasilitas pengolah limbah untuk menetralisir limbah yang dihasilkannya sebelum dibuang ke sungai. Selain itu pencanangan masyarakat peduli lingkungan yang berorientasi kepada kebersihan lingkungan perlu digalakkan agar kebersihan lingkungan secara swadaya dan kesadaran masyarakat dapat terbina dengan baik.

\section{DAFTAR PUSTAKA}

1. BPLHD Propinsi DKI Jakarta, Laporan Pemantauan Kualitas Air Sungai di Propinsi DKI Jakarta Tahun 2004-2005

2. Anonimous. 2004. Pencemaran Sungai di DKI Sudah Membahayakan. [19 Maret 2008] www.sinarharapan.co.id/berita/0403/31/jab02 .html. [19 Maret 2008]

3. Anonimous. 2006. Pencemaran Sungai di Tangerang Mengkhawatirkan. www.tempo interaktif.com/hg/jakarta/2006/08/25/brk,2006 0825-82615,id.html

4. Anonimous. 2004. 77\% Aliran Sungai Jakarta Alami Pencemaran Berat. www.kapanla gi.com $/ \mathrm{h} / 0000151068 . \mathrm{htm} /$ [19 Maret 2008]

5. Anonimous. 2003. Kualitas Air Minum di DKI Makin Turun. www.inawater.com/news/wm view.php? ArtID=603. [19 Maret 2008]

6. Melvika Aruni. 2003. Optimasi pengendalian pencemaran di sungai ciliwung dki jakarta akibat buangan organik industri dan domestik dengan metode program linier. ITB 2003

7. Sutawardi K. 2006. Menyelamatkan Ciliwung. Wetlands International-Indonesia Programme, WI-IP, 2006

8. Anonimous. 2004. Kualitas Air Tanah dan Sungai di Jakarta Mengkhawatirkan. www. tempointeraktif.com/hg/jakarta/2004/10/12/br k,20041012-39,id.html. [19 Maret 2008]

9. Nunuy Nurhayati. 2004. Kualitas Air Tanah dan Sungai di Jakarta Mengkhawatirkan. http://www.tempointeraktif.com/hg/jakarta/20 04/10/12/brk,20041012-39,id.htm [19 Maret 2008] 


\section{LAMPIRAN}

Tabel 2. Data Lokasi Pemantauan Kualitas Air di DKI Jakarta

\begin{tabular}{|c|c|c|c|}
\hline Titik & Sungai & Lokasi Pemantauan & Gol. \\
\hline 1 & S. Ciliwung & Kelapa Dua (Serengseng Sawah) & $B$ \\
\hline 2 & S. Ciliwung & Intake PAM Condet (Kp. Gedong) & B \\
\hline $2 A$ & S. Ciliwung & JI. M.T. Haryono & $\mathrm{B}$ \\
\hline 3 & S. Ciliwung & Sebelum Pintu Air Manggarai & $\mathrm{B}$ \\
\hline $3 A$ & S. Ciliwung & Jl. Halimun (Guntur) & $\mathrm{B}$ \\
\hline 4 & S. Ciliwung & Jl. KH. Mas Mansyur (Karet Tengsin) & $\mathrm{B}$ \\
\hline 5 & S. Ciliwung & Jl. Gudang PLN & $\mathrm{B}$ \\
\hline $5 \mathrm{~A}$ & S. Ciliwung & Jl. Teluk Gong & $\mathrm{B}$ \\
\hline 6 & S. Ciliwung & Jembatan PIK (Muara angke) & D \\
\hline 29 & S. Ciliwung & Jl. Kwitang & $\mathrm{D}$ \\
\hline $29 A$ & S. Ciliwung & Jl. Gjh Mada (Tangki) & $\mathrm{D}$ \\
\hline 30 & S. Ciliwung & Jl. Ancol Marina & $\mathrm{D}$ \\
\hline 31 & S. Ciliwung & JI. Raya Pluit (Penjaringan) & $\mathrm{D}$ \\
\hline 32 & S. Ciliwung & Pompa Pluit & $\mathrm{D}$ \\
\hline 7 & S. Kali baru & Jl. Komplek Zeni Srengseng Sawah & B \\
\hline 8 & S. Cipinang & JI. AURI (Taman Cibubur) & $\mathrm{D}$ \\
\hline $8 \mathrm{~A}$ & S. Cipinang & Jl. Pondok Gede (Tol Taman Mini) & $\mathrm{D}$ \\
\hline $8 \mathrm{~B}$ & S. Cipinang & Jl. Raya Bogor (Komseko) & $\mathrm{D}$ \\
\hline $8 \mathrm{C}$ & S. Cipinang & JI. Kampung Dukuh & $\mathrm{D}$ \\
\hline $8 \mathrm{~F}$ & S. Cipinang & Jl. Ciracas (Pemadam) & $\mathrm{D}$ \\
\hline 9 & S. Cipinang & Jl. Perdana Kusuma & $\mathrm{D}$ \\
\hline 10 & K. Sunter & Pondok Rangon & $\mathrm{D}$ \\
\hline $10 \mathrm{~A}$ & K. Sunter & Lubang Buaya & $\mathrm{D}$ \\
\hline 11 & K. Sunter & Pondok Kelapa Cipinang & $\mathrm{D}$ \\
\hline $11 \mathrm{~A}$ & K. Sunter & Jl. Raden Inten, Rel Kereta & $\mathrm{D}$ \\
\hline 12 & K. Sunter & Jl. Jati Negara Kaum & $\mathrm{D}$ \\
\hline 13 & K. Sunter & Bogasari, Koja Selatan & $\mathrm{D}$ \\
\hline 45 & K. Sunter & Sudarso (Kelapa gading) & $\mathrm{D}$ \\
\hline 14 & S. Krukut & Jl. Pdk Labu & $\mathrm{B}$ \\
\hline 15 & S. Krukut & JI. Pejompongan (Karet Tengsin) & B \\
\hline 16 & K. Mampang & Jl. Ciganjur (Tiga Raksa) & $\mathrm{B}$ \\
\hline 17 & S. Tarum Barat & Bekasi & $B$ \\
\hline 18 & S. Tarum Barat & Halim Perdana Kusuma & B \\
\hline 19 & S. Angke & Ciledug & C \\
\hline 20 & S. Angke & Jl. Daan Mogot (Pool PPD) & $\mathrm{D}$ \\
\hline $20 \mathrm{~A}$ & S. Angke & Pesing Kali Angke & $\mathrm{D}$ \\
\hline 21 & S. Cengkareng Drain & Rel Kereta Api (Kembangan) & $\mathrm{C}$ \\
\hline 22 & S. Cengkareng Drain & Jl. Kapuk Muara & $\mathrm{D}$ \\
\hline 23 & S. Pesanggrahan & Ciputat, Pasar Jumat & C \\
\hline 24 & S. Mookervart & Jl. Daan Mogot, Bir Bintang (KI. Deres) & C \\
\hline $24 \mathrm{~A}$ & S. Mookervart & Jl. Daan Mogot, Pemanacar AL (Rw.Buaya) & C \\
\hline 24B & S. Mookervart & Jl. Daan Mogot, Sumur Bor (Duri Kosambi) & $\mathrm{C}$ \\
\hline $24 \mathrm{C}$ & S. Mookervart & Jl. Daan Mogot, Jembatan TMS (Semanan) & C \\
\hline $24 \mathrm{D}$ & S. Mookervart & Jl. Daan Mogot, Jembatan Bakrie & C \\
\hline 25 & S. Grogol & Jl. Lebak Bulus & C \\
\hline $25 \mathrm{~A}$ & S. Grogol & Jl. Radio Dalam & $\mathrm{C}$ \\
\hline 26 & S. Grogol & RS. Jiwa Grogol & $\mathrm{C}$ \\
\hline 27 & S. Grogol & PLTU Pluit & $\mathrm{D}$ \\
\hline
\end{tabular}




\begin{tabular}{|c|l|l|c|}
\hline 28 & S. Ciledug & Jl. Patra Kuningan & D \\
\hline 33 & S. Kali Baru Timur & Jl. Raya Bogor (YKK) & D \\
\hline 33 A & S. Kali Baru Timur & Jl. Otista III (Cipinang Cempedak) & D \\
\hline 34 & S. Kali Baru Timur & Jl. Ancol/Jemb. Si Manis & D \\
\hline 35 & S. Cakung & Jl. Pulo Gebang & D \\
\hline 36 & S. Buaran & Jl. Pdk. Kelapa & D \\
\hline 37 & S. Cakung Drain & Jl. Raya Bekasi (Cakung Barat) & D \\
\hline 38 & S. Cakung Drain & Cilincing (Pos Polisi) & D \\
\hline 38 A & K. Blencong & Pantai Marunda & D \\
\hline 46 & K. Blencong & Muara Baru Rorotan & D \\
\hline 39 & S. Petukangan & Kawasan PT JIEP & D \\
\hline 40 & S. Petukangan & Jl. Raya Benda (Pegadungan) & D \\
\hline 41 & S. Kamal & Jl. Raya Benda (Pegadungan) & D \\
\hline 42 & S. Kamal & Muara Kamal & D \\
\hline 43 & S. Sepak & Jl. Psr. Bintaro (Ulujami) & C \\
\hline 44 & S. Sekretaris & Jl. Tanah Kusir (Keb. Lama Sltn) & D \\
\hline 47 & S. Bekasi Tengah & PDAM Cakung (Cakung Barat) & D \\
\hline 48 & S. Buaran & Belakang PIK Pulo Gadung & D \\
\hline
\end{tabular}

